\title{
Queering New Media / Art / Histories \& Asking Questions about Nothing
}

\author{
Richard Rinehart \\ Director, Samek Art Museum, Bucknell University
}

\begin{abstract}
Not rooted in a traditional culture or ancestral homeland, Queerness constitutes ephemeral cultures, continually reinvented and reimagined. Queerness is under constant threat of erasure from cultural amnesia and political malice. Academia and the art world have responded to this erasure with alternately heroic and halting efforts.

This paper suggests ways in which this erasure manifests, from historic forces to contemporary discourses. The author attempts to assess various responses to queer erasure in the overlapping enclaves of new media art comprised of artists, academics, writers, and curators. Lastly, this paper will consider how new media art inflects or reframes ongoing conversations around queer social erasure and how artists and art historians work against the forces of nothingness.
\end{abstract}

\section{INTRODUCTION}

This paper will not conform to a standard academic essay format. Rather it will attempt to convey the spirit of a conversation of the same title as this paper that was convened by the New Media Caucus at the 2018 conference of the College Art Association. ${ }^{1}$ I will do this by considering some of the key questions that I posed there in a format that is as brief and quickly moving as was that discussion. In this conversation, context and collectivity were determined to be powerful tools for resisting queer erasure and that they should be extended into traditional academic venues such as journal essays. So, it is worth citing here the other hosts of this conversation: Vagner Whitehead, Professor and Chair, Dept. of Visual Arts, Texas Women's College and Liss LaFleur, Assistant Professor, New Media Art, University of North Texas. They may not be co-authors in the traditional academic sense, but they are co-instigators. This paper should be considered a conference proceeding and can be used in relation to their respective papers to triangulate the nature of this conversation.

“Queer Utopian practice is about 'doing' and 'building' in response to the status of nothingness assigned to us by the heteronormative world.",2

- José Esteban Muñoz 


\section{WHAT IS THIS PARTICULAR NOTHINGNESS?}

This nothingness attempts to envelop and erase queerness. Queer bodies are erased through violence, forced gender conformity, infection, and neglect. Queer identity is erased through pathology, conversion therapy, and the sad safety of the closet. Queer history is erased by hostile or negligent institutions.

Artists resist this erasure with tactics emphasizing visibility, collectivity, multiplicity, and/or coding queer consciousness into the ubiquitous languages of new media cultures. Art historians and curators can resist this erasure by revealing the queer inflection of these resistance tactics or by providing them as context for reading the art work (for instance, through social art history methods.)

\section{IS THERE A QUEER AESTHETIC SEPARATE FROM QUEER CREATORS OR SUBJECTS?}

It could be a mistake to generalize and over-determine what is "queer art." For instance, not every artist who incorporates queerness in their work necessarily intends to resist erasure or uses the tactics listed above. Resisting erasure is one way to read such works - one that emphasizes the active "queering" art and art history as opposed to passive "queer" art. Reading works this way should not reduce such works to one dimension. It does not imply a movement, genre, or other taxonomical absolute.

Conversely, atomizing these works into mere instances of "contemporary art" and failing to recognize the queering effect of such work serves to re-inscribe the very erasure such work can be read as foiling. In a parallel vein, attempting to identify a queer aesthetic separate from queer creators and subjects can be seen as art history applying traditional and "objective" methods for locating aesthetics outside of social context and thus, again, erasing these bodies and identities.

Perhaps one way forward toward queering media art history is to position a queer aesthetic as having multiple non-exclusive modalities among which prominently positioning queer creators or subjects are two primary modes. The express acknowledgement of a queer subject and resulting visibility is important, for instance, in the work of Zach Blas. In Blas' Fag Face Mask, the scanned data from the faces of groups of queer men are digitally combined into one blob-like mask that is intended to thwart facial recognition technologies (specifically queer-targeted recognition software. $)^{3}$

Other artists working in a queer aesthetic may employ different modalities, like Amir Nikravan, whose abstract images avoid quick queer identification but, instead, connote the repetition and organic contours of masses of bodies and thus signal - in the context of Nikravan's comments about his work - a kind of queer collectivity. ${ }^{4}$ Collectivity is a queered modality in the form of sex-positive orgies, activist events, and it resists the oppressive strategy of isolation that is necessary for forms of erasure like psychological pathology, conversion therapy, or the closet.

\section{HOW DO WE ENSURE THAT ETHICS ARE INCORPORATED INTO QUEERING MEDIA / ART / HISTORY?}


There was a time when "queering" an aspect of the social fabric was considered (by many in the arts or academia at least) as a goal unto itself; a positive act that made space for queerness in society and consciousness. However, following the important early history of queer liberation movements, counter-forces have seized upon the same tactic - toward a different end - in the form of "pink-washing." For instance Milo Yiannopoulos queered American politics, but toward the end of making or preserving room for anti-queer political forces. At the current historical moment, "queering" media, art, or art history cannot be presumed to be an automatic good. Ethics must be considered and incorporated into respective art works and art histories explicitly.

New media art has been, for its own short history, alternately excluded, neglected, and fetishized by the mainstream art world. As such, some in the communities behind such art came to adopt the identities of outsiders and mavericks - that is to say the familiar position of the avant garde. As new media art has been slowly welcomed into the mainstream art world (one might say absorbed in its own kind of historical erasure) these positions have softened but their effects linger. It is an unfortunate but common phenomenon that those who are oppressed through one aspect of their identity may identify as victims or targets and forget that other aspects of their identity may facilitate the oppression of a different group. Such was the case with early feminist and queer liberation movements that were dominated by cis-gendered white women and men respectively to the exclusion of trans voices and people of color.

New media art - as a field and community - may have suffered from a similar lack of intersectional consciousness. We've been so focused on our minority status in the art world that many of us have not paid attention to the minoritized voices we have been excluding from our efforts to protest, to celebrate, or grow our own histories and theories. In new media art literature, the number of citations of Deleuze and Guattari vastly outnumber mentions of the equally complex works and histories of Afrofuturism or of another creative duo Mendi and Keith Obadike's important work on race, media, and art. ${ }^{5}$

\section{JUST ONE MORE QUESTION}

Queering new media / art / histories can be seen as a utopian project. After all, both new media (art and more generally) and queerness have historical associations with utopianism. These historic utopias have too often been proposed as technocratic dream states or frivolous apolitical parties - but utopia may yet be a neutral and natural meeting place for new media / art / histories. A utopian approach prompts us to ask new questions of new media art. For instance, beyond asking, "How does this art fit into art history?" we might ask, "How does this art re-imagine art history?" Utopia allows us to confront nothingness with equally powerful imaginaries and it urges us to ask questions that are social and, ultimately, ethical like, "Who belongs and who doesn't?" 


\section{REFERENCES}

1. Association, College Art. "Schedule." CAA 106th Annual Conference, New York, February 21-24, 2018. Accessed June 21, 2018. https://conference.collegeart.org/programs/queering-newmedia-art-asking-questions-about-nothing/.

2. José Esteban Muñoz. Cruising utopia: The then and there of queer futurity. NYU Press, 2009, 118.

3. "Facial Weaponization Suite." Zach Blas. Accessed June 21, 2018.

http://www.zachblas.info/works/facial-weaponization-suite/.

4. Catherine Wagley. "When Creating Paintings, Amir Nikravan Tries to Mimic Photoshop." L.A. Weekly. 2016. Accessed September 27, 2016. http://www.laweekly.com/arts/when-creatingpaintings-amir-nikravan-tries-to-mimic-photoshop-5146843.

5. "Mendi Keith Obadike." Blackness for Sale. Accessed June 21, 2018. http://blacknetart.com/.

\section{AUTHOR BIO}

Richard Rinehart is Director and Chief Curator of the Samek Art Museum at Bucknell University in the United States. He has served as Digital Media Director \& Adjunct Curator at the UC Berkeley Art Museum and as curator at New Langton Arts and for the San Jose Arts Commission. He juried for the Rockefeller Foundation, Rhizome.org, and others. Richard has taught courses on art and new media at UC Berkeley, UC Santa Cruz, the San Francisco Art Institute and elsewhere. He served on the boards of the Berkeley Center for New Media, New Langton Arts, and the Museum Computer Network. He has lead NEA and NEH-funded national research projects on new media, art, preservation, and museums. He has recently published a book with MIT Press on preserving digital culture, co- authored with Jon Ippolito - ReCollection: Art, New Media, \& Social Memory (http://re-collection.net) 